\title{
PENGARUH PERBANDINGAN TALAS KIMPUL (Xanthosoma sagittifolium) DENGAN JAMUR TIRAM PUTIH (Pleurotus ostreatus) TERHADAP KARAKTERISTIK SATE LILIT KELADI
}

\author{
The Effect of Xanthosoma (Xanthosoma sagittifolium) and White Oyster Mushroom \\ (Pleurotus ostreatus) Ratio on The Characteristics of Sate Lilit Keladi \\ Putu Lisa Adinda Putri ${ }^{1)}$, Ni Made Yusa ${ }^{2)}$, I Ketut Suter ${ }^{2)}$ \\ ${ }^{1)}$ Mahasiswa Program Studi Ilmu dan Teknologi Pangan, Fakultas Teknologi Pertanian, Unud \\ ${ }^{2}$ Dosen Program Studi Ilmu dan Teknologi Pangan, Fakultas Teknologi Pertanian, Unud \\ Kampus Bukit Jimbaran, Badung-Bali
}

\begin{abstract}
This study aims to determine the effect of xanthosoma and white oyster mushroom on the characteristics of sate lilit keladi, and to know the right ratio of xanthosoma and white oyster mushroom on the characteristics of sate lilit keladi. The experimental design used was completely randomized design with the treatment ratio of xanthosoma and oyster mushroom, which consists of 6 levels such as: 100\%:0\%, 90\%:10\%, 80\%:20\%, 70\% $: 30 \%, 60 \%: 40 \%, 50 \%: 50 \%$. The treatment was repeated 3 times to obtained 18 units of the experiment. The data were analysed by analysis of variance and if the treatment had an effect on the variable then continued with Duncan test. The result showed xanthosoma and white oyster mushroom ratio had a significant effect on water content, ash content, fat content, protein content, carbohydrate content, coarse fiber content, hardness, color (hedonic), aroma (hedonic), texture (hedonic and scoring), taste (hedonic and scoring) and overall acceptance (hedonic). Comparison of 50\% xanthosoma and 50\% white oyster mushroom had the best characteristics, with 52,86 \% water content, 3,31\% ash content, 6,52\% protein content, $24,57 \%$ fat content, $12,74 \%$ carbohydrate content, 35,88\% coarse fiber content, $0,11 \mathrm{~kg} / 5 \mathrm{~mm}$ hardness, color liked, aroma liked, texture mushy and rather liked, typical taste rather keladi and liked and overall acceptance liked.
\end{abstract}

Keywords : xanthosoma, white oyster mushroom, sate lilit

\section{PENDAHULUAN}

Indonesia memiliki beragam makanan, minuman, dan kudapan yang berbeda di tiap daerah sebagai ciri khas dari daerah asal makanan tersebut. Pulau Bali merupakan salah satu daerah yang memiliki berbagai kuliner tradisional. Terdapat 281 jenis makanan tradisional, salah satu pangan tradisional khas Bali adalah sate lilit (Suter et al., 1999). Sate lilit merupakan makanan tradisional khas Bali, bahan utama yang digunakan dalam pembuatan sate lilit adalah daging yang sudah dicincang kemudian dicampurkan dengan cara diulek bersama kelapa parut dan bumbu sehingga terbentuk adonan. Adonan kemudian dililitkan pada tangkai sate secara melilit kemudian dipanggang di atas arang. Istilah lilit dalam Bahasa Bali memiliki arti melilitkan adonan pada tangkai sate secara melilit (Ariani, 2017). Bahan utama daging yang digunakan dalam pembuatan sate lilit sangat beragam, ada yang menggunakan daging ayam, daging babi dan ikan laut

*Korespondensi Penulis:

Email: lisaapp@yahoo.com ${ }^{1}$ 
(Purnamayanti, 2016).

Di Desa Pedawa, Singaraja terdapat sate lilit yang tidak menggunakan daging sebagai bahan utama yang bernama sate lilit keladi. Sate lilit ini disebut sate lilit keladi karena menggunakan talas kimpul (biasa disebut keladi oleh warga setempat) sebagai bahan utamanya. Sate lilit keladi tinggi dari segi kandungan karbohidrat dan karbohidrat yang terkandung pada talas kimpul sebesar 34,2 g/100g (Ridal, 2003). Talas kimpul juga memiliki kekurangan dari segi kandungan protein. Untuk meningkatkan kandungan protein perlu dilakukan penambahan bahan pangan pada pembuatan sate lilit keladi yang dapat digunakan sebagai sumber protein nabati pengganti daging seperti jamur tiram putih. Jamur tiram putih selain sebagai sumber protein nabati juga dapat menjadi sumber serat. Jamur tiram memiliki kandungan protein sebesar $27 \%$ dan kandungan serat sebesar 11,5\% (Cahyana et.al., 2001). Jamur tiram putih merupakan sayuran yang memiliki tekstur paling mendekati daging sehingga jamur tiram putih biasa diolah sebagai makanan simulasi daging bagi para vegetarian.

Sate lilit ini diharapkan dapat memiliki nilai gizi yang tinggi dari segi karbohidrat, protein, dan serat serta dapat digunakan sebagai alternatif makanan bagi para vegetarian yang ingin menikmati olahan makanan dalam bentuk sate lilit sehingga perlu dilakukan penelitian lebih lanjut. Tujuan penelitian ini adalah mengetahui perbandingan talas kimpul dan jamur tiram putih yang tepat sehingga dihasilkan sate lilit dengan karakteristik terbaik.

\section{METODE PENELITIAN}

\section{Tempat dan Waktu Penelitian}

Penelitian ini dilaksanakan di Laboratorium Pengolahan Pangan, Laboratorium Analisis
Pangan dan Laboratorium Rekayasa Proses dan Pengendalian Mutu Fakultas Teknologi Pertanian, Universitas Udayana. Pelaksanaan penelitian dimulai dari April sampai Juni 2018.

\section{Bahan dan Alat}

Bahan-bahan yang digunakan dalam penelitian ini terdiri dari bahan baku, bahan tambahan dan bahan kimia. Bahan baku terdiri dari talas kimpul dan jamur tiram putih. Talas kimpul yang digunakan diperoleh dari Desa Pedawa, Singaraja, sedangkan jamur tiram yang digunakan diperoleh dari pasar Sanglah. Bahan tambahan yang terdiri dari kelapa parut, garam, kunyit, cabai besar, bawang putih, kencur, cabai kecil dan ketumbar diperoleh dari pasar Sanglah. Bahan kimia yang digunakan dalam melakukan analisis proksimat meliputi alkohol, tablet kjeldahl, $\mathrm{HCl}, \mathrm{H}_{2} \mathrm{SO}_{4}, \mathrm{NaOH}$, asam borat, indikator phenolphtalein (PP) dan N-Heksan.

Alat yang digunakan untuk membuat sate lilit adalah pisau, talenan, waskom, panci, kukusan, blender, timbangan digital, cobek, pemanggangan, dan sendok. Alat yang digunakan untuk analisis sifat fisik dan kimia adalah lumpang, desikator, cawan porselin, oven (Memmert), timbangan analitik (Shimadzu), pinset, muffle (Daihan), labu kjeldahl (Pyrex), labu erlenmeyer (Pyrex), gelas beaker (Pyrex), gelas ukur (Pyrex), destilator, biuret (Pyrex), pipet volume (Pyrex), pompa karet, labu takar (Pyrex), labu lemak (Pyrex), soxhlet, pendingin balik, benang wol, kertas whatman no 42, kertas saring, corong, TA-XT Plus dan perangkat komputer

\section{Rancangan Penelitian}

Rancangan yang digunakan pada
penelitian ini adalah Rancangan Acak
Lengkap (RAL) yang terdiri dari 6
perlakuan. Masing-masing perlakuan
diulang sebanyak 3 kali sehingga diperoleh


18 unit percobaan. Perbandingan talas kimpul dengan jamur tiram putih pada penelitian ini adalah sebagai berikut : $\mathrm{F} 1=$ $100 \%: 0 \%, \mathrm{~F} 2=90 \%: 10 \%, \mathrm{~F} 3=80 \%:$ $20 \%, \mathrm{~F} 4=70 \%: 30 \%, \mathrm{~F} 5=60 \%: 40 \%, \mathrm{~F} 6$ $=50 \%: 50 \%$. Data yang diperoleh dari hasil penelitian dianalisis dengan sidik ragam (ANOVA) dan perlakuan yang berpengaruh terhadap variable akan dilanjutkan dengan uji Duncan (Gomez dan Gomez, 1995).

\section{Pelaksanaan Penelitian}

Pelaksanaan penelitian dimulai dengan persiapan bahan. Bahan yang digunakan kemudian ditimbang sesuai formula. Formula bahan sate lilit keladi dapat dilihat pada Tabel 1.

Tabel 1. Formula sate lilit keladi

\begin{tabular}{rlcccccc}
\hline No. & Komposisi & \multicolumn{5}{c}{ Perlakuan } \\
\cline { 3 - 7 } & & F1 & F2 & F3 & F4 & F5 & F6 \\
\hline 1. & Talas kimpul \% & 100 & 90 & 80 & 70 & 60 & 50 \\
2. & Jamur tiram \% & 0 & 10 & 20 & 30 & 40 & 50 \\
3. & Kelapa parut \% & 35 & 35 & 35 & 35 & 35 & 35 \\
4. & Garam \% & 1,2 & 1,2 & 1,2 & 1,2 & 1,2 & 1,2 \\
5. & Kunyit \% & 1 & 1 & 1 & 1 & 1 & 1 \\
6. & Kencur \% & 0,5 & 0,5 & 0,5 & 0,5 & 0,5 & 0,5 \\
7. & Cabai besar \% & 1,5 & 1,5 & 1,5 & 1,5 & 1,5 & 1,5 \\
8. & Cabai rawit \% & 2,5 & 2,5 & 2,5 & 2,5 & 2,5 & 2,5 \\
9. & Bawang putih \% & 3 & 3 & 3 & 3 & 3 & 3 \\
10. & Ketumbar \% & 0,3 & 0,3 & 0,3 & 0,3 & 0,3 & 0,3 \\
\hline
\end{tabular}

Keterangan : \% bahan berdasarkan jumlah talas kimpul dengan jamur tiram

Proses pembuatan sate lilit keladi dengan jamur meliputi 4 tahapan : tahap I dimulai dengan pengupasan kulit talas kimpul dan pemotongan talas kimpul secara dadu dengan ukuran $3 \times 3 \times 3 \mathrm{~cm}$. Talas kimpul yang telah dipotong dadu kemudian dicuci bersih dan dimasukkan pada baskom yang telah berisi air dengan larutan garam $10 \%$ (dari berat talas kimpul), kemudian direndam selama 60 menit (Mayasari, 2010). Talas kimpul yang telah direndam kemudian dicuci dan dikukus selama 30 menit. Tahap II pada jamur tiram putih disortasi untuk menghilangkan bagian yang tidak diinginkan, setelah itu jamur tiram putih dicuci bersih. Jamur yang telah dicuci kemudian dilanjutkan dengan proses steam blanching pada suhu $\pm 80 \mathrm{oC}$ selama 5 menit. Jamur tiram yang telah dikukus kemudian ditiriskan. Tahap III dimulai dari proses pembuatan bumbu diawali dengan melakukan pengupasan pada kunyit, kencur, cabai besar, cabai kecil, dan bawang putih, kemudian dicuci dan dipotong lalu ditimbang sesua formula kemudian dihaluskan dengan menggunakan blender sehingga menjadi bumbu halus (Sekar, 2017). Tahap IV pada talas kimpul yang telah dikukus, jamur tiram putih yang telah di steam blanching, dan kelapa parut yang telah siap kemudian ditimbang sesuai formula. Semua bahan kemudian dicampur menggunakan cobek dengan cara diulek sehingga terbentuk adonan. Adonan kemudian ditimbang masing-masing 15 gram untuk pembagian per tusuk dan langsung dililitkan pada tusuk sate lilit dengan panjang lilit $6 \mathrm{~cm}$. Sate kemudian dipanggang selama \pm 10 menit sambil dibolak-balik (Sekar, 2017).

\section{Variabel yang Diamati}

Dalam penelitian ini variable yang diamati adalah kadar air, kadar abu, kadar protein, kadar lemak, kadar karbohidrat dan kadar 
serat kasar (Sudarmadji et al., 1997), Kekerasan menggunakan alat texture analyser dan sifat sensoris meliputi warna, rasa, aroma, tekstur dan penerimaan keseluruhan menggunakan uji hedonik serta rasa dan tekstur menggunakan uji skoring (Soekarto, 1985).

\section{HASIL DAN PEMBAHASAN}

\section{Karakteristik Bahan Baku}

Karakteristik bahan baku seperti kadar air, kadar abu, kadar protein, kadar lemak, kadar karbohidrat, dan kadar serat kasar dari talas kimpul dan jamur tiram putih yang digunakan dapat dilihat pada Tabel 2. Berdasarkan hasil analisis bahan baku diperoleh kandungan pada talas kimpul : air $(53,52 \%)$, abu $(1,40 \%)$, protein $(1,39 \%)$, lemak $(1,79 \%)$, karbohidrat $(41,90 \%)$ dan serat kasar $(8,12 \%)$. Kandungan pada jamur tiram putih : air $(70,13 \%)$, abu $(0,26 \%)$, protein $(10,78 \%)$, lemak $(3,03 \%)$, karbohidrat $(15,80 \%)$ dan serat kasar $(55,31 \%)$.

Tabel 2. Nilai rata-rata hasil analisis kadar air, kadar abu, kadar protein, kadar lemak, dan kadar serat kasar dari talas kimpul dan jamur tiram putih

\begin{tabular}{|c|c|c|c|c|c|c|}
\hline Bahan & $\begin{array}{c}\text { Kadar } \\
\text { Air }(\%)\end{array}$ & $\begin{array}{c}\text { Kadar } \\
\text { Abu }(\%)\end{array}$ & $\begin{array}{c}\text { Kadar } \\
\text { Protein }(\%)\end{array}$ & $\begin{array}{c}\text { Kadar } \\
\text { Lemak }(\%)\end{array}$ & $\begin{array}{c}\text { Kadar } \\
\text { Karbohidrat }(\%)\end{array}$ & $\begin{array}{c}\text { Kadar Serat } \\
\text { Kasar }(\%)\end{array}$ \\
\hline Talas Kimpul & 53,52 & 1,40 & 1,39 & 1,79 & 41,90 & 8,12 \\
\hline Jamur Tiram & 70,13 & 0,26 & 10,78 & 3,03 & 15,80 & 55,31 \\
\hline
\end{tabular}

\section{Karakteristik Sate Lilit Keladi}

Hasil analisis kadar air, kadar abu, kadar protein, kadar lemak, kadar karbohidrat, dan kadar serat kasar pada sate lilit keladi dapat dilihat pada Tabel 3 .

Tabel 3. Nilai rata-rata hasil analisis kadar air, kadar abu, kadar protein, kadar lemak dan kadar serat kasar pada sate lilit keladi.

\begin{tabular}{|c|c|c|c|c|c|c|}
\hline $\begin{array}{l}\text { Perl } \\
\text { aku } \\
\text { an }\end{array}$ & Kadar Air (\%) & $\begin{array}{l}\text { Kadar } \\
(\%)\end{array}$ & $\begin{array}{l}\text { Kadar Protein } \\
(\%)\end{array}$ & $\begin{array}{l}\text { Kadar Lemak } \\
(\%)\end{array}$ & $\begin{array}{l}\text { Kadar } \\
\text { Karbohidrat }(\%)\end{array}$ & $\begin{array}{l}\text { Kadar Serat } \\
\text { Kasar }(\%)\end{array}$ \\
\hline $\mathrm{P} 1$ & $40,67 \pm 1,14 d$ & $0,17 \mathrm{a}$ & $3,08 \pm 0,09 \mathrm{e}$ & $13,95 \pm 1,06 \mathrm{e}$ & $0,96 \mathrm{a}$ & $11,70 \pm 0,65 \mathrm{e}$ \\
\hline $\mathrm{P} 2$ & $44,65 \pm 0,03 \mathrm{c}$ & $3,74 \pm 0,03 \mathrm{~b}$ & $4,48 \pm 0,20 \mathrm{~d}$ & $15,08 \pm 0,26 \mathrm{e}$ & $32,04 \pm 0,34 b$ & $13,53 \pm 0,69 \mathrm{e}$ \\
\hline P3 & $45,78 \pm 0,88 \mathrm{c}$ & $3,65 \pm 0,05 b c$ & $4,99 \pm 0,22 \mathrm{c}$ & $17,45 \pm 1,25 \mathrm{~d}$ & $28,13 \pm 2,14 \mathrm{c}$ & $19,91 \pm 1,32 \mathrm{~d}$ \\
\hline P4 & $46,19 \pm 0,35 \mathrm{c}$ & $3,57 \pm 0,06 \mathrm{~cd}$ & $5,17 \pm 0,06 \mathrm{bc}$ & $20,00 \pm 0,36 \mathrm{c}$ & $25,06 \pm 0,08 \mathrm{~d}$ & $25,37 \pm 1,84 \mathrm{c}$ \\
\hline P5 & $49,85 \pm 1,28 \mathrm{~b}$ & $3,48 \pm 0,01 \mathrm{~d}$ & $5,43 \pm 0,10 b$ & $21,59 \pm 0,11 b$ & $19,64 \pm 1,42 \mathrm{e}$ & $31,09 \pm 0,79 b$ \\
\hline P6 & $52,86 \pm 1,28 \mathrm{a}$ & $3,31 \pm 0,04 \mathrm{e}$ & $6,52 \pm 0,24 \mathrm{a}$ & $24,57 \pm 0,63 \mathrm{a}$ & $12,74 \pm 1,25 \mathrm{f}$ & $35,88 \pm 1,66 \mathrm{a}$ \\
\hline
\end{tabular}

Keterangan : Nilai rata - rata yang diikuti oleh huruf yang berbeda pada kolom yang sama menunjukkan perlakuan berbeda nyata $(\mathrm{P}<0,05)$

\section{Kadar Air}

Hasil sidik ragam menunjukkan bahwa perbandingan talas kimpul dengan jamur tiram putih berpengaruh sangat nyata $(\mathrm{P}<0,01)$ terhadap kadar air sate lilit keladi. Tabel 3 menunjukkan kadar air sate lilit keladi berkisar antara $40,67 \%$ sampai dengan $52,86 \%$. Kadar air tertinggi sate lilit keladi diperoleh dari perlakuan P6 yaitu $52,86 \%$ sedangkan kadar air terendah sate lilit keladi diperoleh dari perlakuan P1 yaitu 40,67\%. Rendahnya kadar air sate lilit keladi pada perlakuan P1 karena adanya perbedaan kadar air pada bahan baku. Berdasarkan hasil analisis bahan baku kadar air jamur tiram putih sebesar 70,13\% 
sedangkan kadar air talas kimpul sebesar $53,52 \%$.

\section{Kadar Abu}

Hasil sidik ragam menunjukkan bahwa perbandingan talas kimpul dengan jamur tiram putih berpengaruh sangat nyata $(\mathrm{P}<0,01)$ terhadap kadar abu sate lilit keladi. Tabel 3 menunjukkan kadar abu sate lilit keladi berkisar antara 3,31\% sampai dengan 4,05\%. Kadar abu sate lilit keladi tertinggi diperoleh dari perlakuan P1 yaitu $4,05 \%$ sedangkan kadar abu sate lilit keladi terendah diperoleh dari perlakuan P6 yaitu $3,31 \%$. Rendahnya kadar abu sate lilit keladi pada perlakuan P6 karena adanya perbedaan kadar abu pada bahan baku. Berdasarkan hasil analisis bahan baku kadar abu talas kimpul sebesar 1,40\% sedangkan kadar abu jamur tiram putih sebesar $0,26 \%$.

\section{Kadar Protein}

Hasil sidik ragam menunjukkan bahwa perbandingan talas kimpul dengan jamur tiram putih berpengaruh sangat nyata $(\mathrm{P}<0,01)$ terhadap kadar protein sate lilit keladi. Tabel 3 menunjukkan kadar protein sate lilit keladi berkisar antara 3,08\% sampai dengan 6,52\%. Kadar protein sate lilit keladi tertinggi diperoleh dari perlakuan P6 yaitu $6,52 \%$ sedangkan kadar protein sate lilit keladi terendah diperoleh dari perlakuan P1 yaitu $3,08 \%$. Rendahnya kadar protein sate lilit keladi pada perlakuan P1 karena adanya perbedaan kadar protein pada bahan baku. Berdasarkan hasil analisis bahan baku kadar protein jamur tiram putih sebesar 10,78\% sedangkan kadar protein talas kimpul sebesar $1,39 \%$.

\section{Kadar Lemak}

Hasil sidik ragam menunjukkan bahwa perbandingan talas kimpul dengan jamur tiram putih berpengaruh sangat nyata $(\mathrm{P}<0,01)$ terhadap kadar lemak sate lilit keladi. Tabel 3 menunjukkan kadar lemak sate lilit keladi berkisar antara 13,95\% sampai dengan $24,57 \%$. Kadar lemak sate lilit keladi tertinggi diperoleh dari perlakuan P6 yaitu $24,57 \%$ sedangkan kadar lemak sate lilit keladi terendah diperoleh dari perlakuan P1 yaitu $13,95 \%$ serta tidak berbeda dengan perlakuan P2. Rendahnya kadar lemak sate lilit keladi pada perlakuan P1 karena adanya perbedaan kadar lemak pada bahan baku. Berdasarkan hasil analisis bahan baku kadar lemak jamur tiram putih sebesar 3,03\% sedangkan kadar lemak talas kimpul sebesar 1,79\%. Kadar lemak sate lilit keladi juga mengalami peningkatan karena adanya penambahan kelapa parut pada pembuatan sate lilit keladi.

\section{Kadar Karbohidrat}

Hasil sidik ragam menunjukkan bahwa perbandingan talas kimpul dengan jamur tiram putih berpengaruh sangat nyata $(\mathrm{P}<0,01)$ terhadap kadar karbohidrat sate lilit keladi. Tabel 3 menunjukkan kadar karbohidrat sate lilit keladi berkisar antara $12,74 \%$ sampai dengan 38,25\%. Kadar karbohidrat sate lilit keladi tertinggi diperoleh dari perlakuan P1 yaitu $38,25 \%$ sedangkan kadar karbohidrat sate lilit keladi terendah diperoleh dari perlakuan P6 yaitu 12,74\%. Berdasarkan hasil analisis bahan baku kadar karbohidrat talas kimpul sebesar 41,90\% sedangkan kadar karbohidrat jamur tiram putih sebesar $15,80 \%$. Kadar karbohidrat dihitung dengan metode by different yaitu dengan menghitung selisih antara $100 \%$ dengan total kadar air, kadar abu, kadar protein dan kadar lemak.

\section{Kadar Serat Kasar}

Hasil sidik ragam menunjukkan bahwa perbandingan talas kimpul dengan jamur tiram putih berpengaruh sangat nyata $(\mathrm{P}<0,01)$ terhadap kadar serat kasar sate lilit keladi. Tabel 3 menunjukkan kadar serat kasar sate lilit keladi berkisar antara $11,70 \%$ sampai dengan 35,88\%. Kadar serat kasar sate lilit keladi tertinggi diperoleh dari perlakuan P6 
yaitu $35,88 \%$ sedangkan kadar serat kasar sate lilit keladi terendah diperoleh dari perlakuan P1 yaitu $11,70 \%$ serta tidak berbeda dengan perlakuan P2. Rendahnya kadar serat kasar sate lilit keladi pada perlakuan P1 karena adanya perbedaan kadar serat kasar pada bahan baku. Berdasarkan hasil analisis bahan baku kadar serat kasar jamur tiram putih sebesar $55,31 \%$ sedangkan kadar serat kasar talas kimpul sebesar $8,12 \%$.

\section{Kekerasan}

Hasil sidik ragam menunjukkan bahwa perbandingan talas kimpul dengan jamur tiram putih berpengaruh sangat nyata $(\mathrm{P}<0,01)$ terhadap nilai kekerasan sate lilit keladi. Tabel 4 menunjukkan nilai kekerasan sate lilit keladi berkisar antara $0,1135 \mathrm{~kg} / 5 \mathrm{~mm}$ sampai dengan $0,4428 \mathrm{~kg} / 5 \mathrm{~mm}$. Nilai kekerasan sate lilit keladi tertinggi diperoleh dari perlakuan P1 yaitu $0,4428 \mathrm{~kg} / 5 \mathrm{~mm}$ sedangkan nilai kekerasan sate lilit keladi terendah diperoleh dari perlakuan P6 yaitu $0,1135 \mathrm{~kg} / 5 \mathrm{~mm}$. Kekerasan sate lilit keladi menurun pada perlakuan P6 karena meningkatnya penambahan jamur tiram putih. Jamur dapat meningkatkan absorpsi air sehingga kandungan air pada produk meningkat dan keberadaan air dalam suatu produk akan mempengaruhi kekerasan, karena air yang terdapat didalamnya akan mempengaruhi lembek atau kerasnya suatu produk (Apriliyani, 2010). Semakin tinggi kandungan air pada sate lilit keladi maka kekerasan produk akan menurun.
Tabel 4. Nilai rata-rata kekerasan sate lilit keladi

\begin{tabular}{lc}
\hline Sampel & Kekerasan $(\mathrm{Kg} / 5 \mathrm{~mm})$ \\
\hline P1 (100:0) & $0,44 \pm 0,04 \mathrm{a}$ \\
P2 (90:10) & $0,32 \pm 0,03 \mathrm{~b}$ \\
P3 (80:20) & $0,27 \pm 0,01 \mathrm{c}$ \\
P4 (70:30) & $0,21 \pm 0,01 \mathrm{~d}$ \\
P5 (60:40) & $0,17 \pm 0,00 \mathrm{e}$ \\
P6 (50:50) & $0,11 \pm 0,00 \mathrm{f}$ \\
\hline Keterangan : & Nilai rata - rata yang diikuti oleh \\
& huruf yang berbeda pada kolom \\
& yang sama menunjukkan perlakuan \\
& berbeda nyata $(\mathrm{P}<0,05)$
\end{tabular}

\section{Karakteristik Sensoris}

Karakteristik sensoris sate lilit keladi dilakukan dengan uji hedonik terhadap warna, aroma, tekstur, rasa dan penerimaan keseluruhan. Uji skoring dilakukan terhadap tekstur dan rasa sate lilit keladi. Nilai ratarata uji hedonik terhadap warna, aroma, tekstur, rasa dan penerimaan keseluruhan sate lilit keladi dapat dilihat pada Tabel 5. Nilai rata-rata uji skoring terhadap tekstur dan rasa dapat dilihat pada Tabel 6 .

\section{Warna}

Hasil sidik ragam menunjukkan bahwa perbandingan talas kimpul dengan jamur tiram putih berpengaruh tidak nyata $(\mathrm{P}>0,05)$ terhadap warna sate lilit keladi. Tabel 5 menunjukkan bahwa nilai rata-rata kesukaan panelis terhadap warna sate lilit keladi berkisar antara 5,70 (suka) sampai dengan 5,75 (suka). Hal ini disebabkan karena bahan baku yang digunakan tidak memiliki warna yang dapat mempengaruhi tingkat kesukaan warna. 
Tabel 5. Nilai rata - rata hasil uji hedonik warna, aroma, tekstur, rasa dan penerimaan keseluruhan sate lilit keladi

\begin{tabular}{llllll}
\hline Sampel & Warna & Aroma & Tekstur & Rasa & Penerimaan keseluruhan \\
\hline P1 (100:0) & $5,70 \mathrm{a}$ & $5,55 \mathrm{a}$ & $4,65 \mathrm{c}$ & $5,10 \mathrm{c}$ & $5,15 \mathrm{~d}$ \\
P2 (90:10) & $5,70 \mathrm{a}$ & $5,60 \mathrm{a}$ & $5,05 \mathrm{bc}$ & $5,30 \mathrm{bc}$ & $5,35 \mathrm{~cd}$ \\
P3 (80:20) & $5,75 \mathrm{a}$ & $5,65 \mathrm{a}$ & $5,00 \mathrm{bc}$ & $5,25 \mathrm{bc}$ & $5,50 \mathrm{bcd}$ \\
P4 (70:30) & $5,75 \mathrm{a}$ & $5,65 \mathrm{a}$ & $5,35 \mathrm{ab}$ & $5,65 \mathrm{ab}$ & $5,70 \mathrm{bc}$ \\
P5 (60:40) & $5,70 \mathrm{a}$ & $5,55 \mathrm{a}$ & $5,50 \mathrm{a}$ & $5,65 \mathrm{ab}$ & $5,85 \mathrm{ab}$ \\
P6 (50:50) & $5,75 \mathrm{a}$ & $5,70 \mathrm{a}$ & $5,75 \mathrm{a}$ & $5,95 \mathrm{a}$ & $6,25 \mathrm{a}$ \\
\hline
\end{tabular}

Keterangan : Nilai rata - rata yang diikuti oleh huruf yang berbeda pada kolom yang sama menunjukkan perlakuan berbeda nyata $(\mathrm{P}<0,05)$

Kriteria hedonik : 1 (sangat tidak suka); 2 (tidak suka); 3 (agak tidak suka); 4 (Biasa); 5 (agak suka); 6 (suka); 7 (sangat suka)

Tabel 6. Nilai rata - rata hasil uji skoring rasa dan tekstur sate lilit keladi

\begin{tabular}{|c|c|c|}
\hline Sampel & Tekstur & Rasa \\
\hline P1 (100:0) & $3,70 \mathrm{a}$ & $4,15 \mathrm{a}$ \\
\hline P2 (90:10) & $3,40 a b c$ & $3,90 \mathrm{a}$ \\
\hline P3 (80:20) & $3,35 \mathrm{bc}$ & $3,50 \mathrm{~b}$ \\
\hline P4 (70:30) & $3,45 \mathrm{ab}$ & $3,35 \mathrm{bc}$ \\
\hline P5 $\quad(60: 40)$ & $3,10 \mathrm{~cd}$ & $3,40 \mathrm{~b}$ \\
\hline P6 (50:50) & $3,00 \mathrm{~d}$ & $3,05 \mathrm{c}$ \\
\hline
\end{tabular}

Keterangan : Nilai rata - rata yang diikuti oleh huruf yang berbeda pada kolom yang sama menunjukkan perlakuan berbeda nyata $(\mathrm{P}<0,05)$

Nilai skoring tekstur : 1 (amat sangat lembek); 2 (sangat lembek); 3 (lembek); 4 (agak lembek); 5 (keras);

Nilai skoring rasa : 1 (sangat tidak khas keladi); 2 (tidak khas keladi); 3 (agak khas keladi); 4 (khas keladi); 5 (sangat khas keladi)

\section{Aroma}

Hasil sidik ragam menunjukkan bahwa perbandingan talas kimpul dengan jamur tiram putih berpengaruh tidak nyata $(\mathrm{P}>0,05)$ terhadap kesukaan aroma sate lilit keladi. Tabel 5 menunjukkan bahwa nilai rata-rata kesukaan panelis berkisar antara 5,55 (suka) sampai dengan 5,70 (suka). Hal ini disebabkan karena pada talas kimpul dan jamur tiram putih tidak memiliki aroma yang dominan.

\section{Tekstur}

Hasil sidik ragam menunjukkan bahwa perbandingan talas kimpul dengan jamur tiram putih berpengaruh sangat nyata $(\mathrm{P}<0,01)$ terhadap kesukaan tekstur (uji hedonik) sate lilit keladi. Tabel 5 menunjukkan bahwa nilai uji hedonik terhadap tekstur sate lilit keladi berkisar antara 4,65 (agak suka) sampai dengan 5,75 (suka). Nilai rata-rata uji skoring terhadap tekstur sate lilit keladi tertinggi diperoleh dari perlakuan P6 yaitu 5,75 (suka), sedangkan nilai terendah diperoleh dari perlakuan P1 yaitu 4,65 (agak suka). Perbandingan talas kimpul dengan jamur tiram putih berpengaruh sangat nyata $(\mathrm{P}<0,01)$ terhadap tingkatan tekstur (uji skoring) sate lilit keladi. Tabel 6 menunjukkan bahwa bahwa nilai uji skoring terhadap tekstur sate lilit keladi berkisar antara 3,00 (lembek) sampai dengan 3,70 (agak lembek). Nilai rata-rata uji skoring terhadap tekstur sate lilit keladi tertinggi diperoleh dari perlakuan P1 yaitu 3,70 (agak lembek), sedangkan nilai terendah diperoleh dari perlakuan P6 yaitu 3,00 (lembek).

\section{Rasa}

Hasil sidik ragam menunjukkan bahwa 
perbandingan talas kimpul dengan jamur tiram putih berpengaruh sangat nyata $(\mathrm{P}<0,01)$ terhadap kesukaan rasa (uji hedonik) sate lilit keladi. Tabel 5 menunjukkan bahwa nilai uji hedonik terhadap rasa sate lilit keladi berkisar antara 5,10 (agak suka) sampai dengan 5,95 (suka). Nilai rata-rata uji hedonik terhadap rasa sate lilit keladi tertinggi diperoleh dari perlakuan P6 yaitu 5,95 (suka) sedangkan nilai terendah diperoleh dari perlakuan P1 yaitu 5,1 (agak suka). Perbandingan talas kimpul dengan jamur tiram putih berpengaruh sangat nyata $(\mathrm{P}<0,01)$ terhadap tingkatan rasa (uji skoring) sate lilit keladi. Tabel 6 menunjukkan bahwa nilai uji skoring terhadap rasa sate lilit keladi berkisar antara 3,05 (agak khas keladi) sampai dengan 4,15 (khas keladi). Nilai ratarata uji skoring terhadap rasa sate lilit keladi tertinggi diperoleh dari perlakuan P1 yaitu 4,15 (khas keladi) serta tidak berbeda dengan perlakuan P2, sedangkan nilai terendah diperoleh dari perlakuan P6 yaitu 3,05 (agak khas keladi).

\section{Penerimaan Keseluruhan}

Hasil sidik ragam menunjukkan bahwa perbandingan talas kimpul dengan jamur tiram putih berpengaruh sangat nyata $(\mathrm{P}<0,01)$ terhadap penerimaan keseluruhan sate lilit keladi. Tabel 5 menunjukkan bahwa nilai uji hedonik terhadap penerimaan keseluruhan sate lilit keladi berkisar antara 5,15 (agak suka) sampai dengan 6,25 (suka). Nilai rata-rata uji hedonik terhadap penerimaan keseluruhan sate lilit keladi tertinggi diperoleh dari perlakuan P6 yaitu 6,25 (suka) dengan persentase 50\% talas kimpul dengan $50 \%$ jamur tiram putih. Nilai rata-rata terendah diperoleh pada perlakuan P1 yaitu 5,15 (agak suka).

\section{SIMPULAN DAN SARAN}

\section{Simpulan}

Berdasarkan penelitian yang telah dilakukan maka dapat disimpulkan beberapa hal sebagai berikut:

1. Perbandingan talas kimpul dengan jamur tiram putih berpengaruh terhadap kadar air, kadar abu, kadar protein, kadar lemak, kadar serat kasar, hardness, tingkat tekstur (hedonik dan skor) rasa (hedonik dan skor) dan penerimaan keseluruhan (hedonik) sate lilit keladi.

2. Perbandingan 50\% talas kimpul : $50 \%$ jamur tiram putih menghasilkan karakteristik terbaik sate lilit keladi dengan kriteria kadar air 52,86 \%, kadar abu $3,31 \%$, kadar protein $6,52 \%$, kadar lemak $24,57 \%$, kadar karbohidrat 12,74\%, kadar serat kasar 35,88\%, kekerasan 0,11 $\mathrm{kg} / 5 \mathrm{~mm}$, warna suka, aroma suka, tekstur lembek dan suka, rasa agak khas keladi dan suka, penerimaan keseluruhan suka.

\section{Saran}

Berdasarkan hasil penelitian ini disarankan untuk menggunakan perbandingan $50 \%$ talas kimpul : 50\% jamur tiram putih dalam proses pembuatan sate lilit keladi dan perlu dilakukan penelitian lanjut untuk masa simpan sate lilit keladi

\section{DAFTAR PUSTAKA}

Ariani, R.P. 2017. Mengenal Kulinerr Bali. Rajawali Pers, Depok

Cahyana, Y.A., Muchrodji dan M. Bakrun, 2001. Pembibitan, Pembudidayaan, Analisis Usaha Jamur Tiram. Penebar Swadaya, Jakarta

Gomez, K.A. dan A.A. Gomez. 1995. Prosedur Statistik Untuk Penelitian Pertanian. Universitas Indonesia Press, Jakarta.

Mayasari, N. 2010. Pengaruh Penambahan Larutan Asam dan Garam Sebagai Upaya Reduksi Oksalat Pada Tepung 
Talas (Colocasia esculenta). Skripsi. Tidak Dipublikasikan. Institut Pertanian Bogor, Bogor.

Purnamayanti, N.P.I. 2016. Analisis faktorfaktor bauran pemasaran yang mempengaruhi keputusan pembelian konsumen sate lilit ikan pada warung lesehan merta sari pesinggahan klungkung. Rekayasa dan Manajemen Agroindustri. 4(3):85-92

Sekar, M. 2017. Proses Pembuatan Sate Lilit Keladi. Oral Komunikasi, Singaraja

Soekarto, S.T. 1985. Penelitian Organoleptik Untuk Industri Pangan dan Hasil Pertanian. Bharata Karya Aksara, Jakarta.

Sudarmadji, S.,B. Haryono dan Suhardi. 1997. Prosedur Analisa Bahan Makanan dan Pertanian. Liberty, Yogyakarta.

Suter, I.K., I.W. Arga, I.N.K. Putra, N.S. Antara, A.A.S. Jelantik, M. Hartawan dan I.K. Setiawan. 1999. Inventarisasi 50 Jenis Makanan dan Minuman Daerah. Pusat Kajian Makanan Tradisional Madya Universitas Udayana, Bukit Jimbaran 